Article

\title{
Geostrategic Renewable Energy Transition in Turkey: Organizational Strategies Towards an Energy Autonomous Future
}

\author{
Özge Dolunay \\ Chair of Social and Population Geography, University of Bayreuth, 95440 Bayreuth, Germany; \\ E-Mail: oezge.dolunay@uni-bayreuth.de
}

Submitted: 28 February 2020 | Accepted: 24 June 2020 | Published: 11 September 2020

\begin{abstract}
The geographical location of Turkey in the Asia Minor places the country in a delicate geostrategic position determined by its history, ideological structure, politics and energy economy. The Turkish government has defined its main energy strategies with the goal of reaching $30 \%$ renewables by 2023 . Key strategies declared are the prioritization of energy supply security, the consideration of environmental concerns, and an increase in efficiency and productivity through the establishment of transparent and competitive market conditions through reform and liberalization. This article analyses the renewable energy (RE) transition of Turkey from a fully centralised energy management model towards a system of partially centralization through the unbundling of utility companies. Analysis will utilize Michael Mann's theory on the four sources of social power as an alternative organizational means of social control and the interrelations of ideological, economic, political and military power. The recent history of Turkey's RE transition and government plans for sector development will be investigated from a socio-spatial and organizational perspective. Furthermore, the way in which these socio-spatial relations have been shaping electricity market liberalization and the preparedness of the state to share its power with non-state actors is discussed. The potential of a centralised RE management model to inspire 'decentralised' RE management in other geographies is considered. In conclusion, key factors in the organisation of the (de)centralised electricity transitions are found to be dependent on history, geography, and overlapping relations of social power.
\end{abstract}

\section{Keywords}

decentralization; development; electricity market; energy transition; renewable energy; social power; Turkey

\section{Issue}

This article is part of the issue "Politics and (Self-)Organisation of Electricity System Transitions in a Global North-South Perspective" edited by Eberhard Rothfuß (University of Bayreuth, Germany) and Festus Boamah (University of Bayreuth, Germany).

(C) 2020 by the author; licensee Cogitatio (Lisbon, Portugal). This article is licensed under a Creative Commons Attribution 4.0 International License (CC BY).

\section{Introduction}

Energy autonomy (or dependency) shapes both the trajectory of a country's socio-economic development as well as the nature of its international relations. Scheer (2007, p. 231) describes the guiding concept of energy autonomy as the goal of making energy available in a way that is self-determined, not heteronomous; free and independent of external constraints, and outside intervention. Scheer (2007, p. 231) also states that in the long run, all these dimensions of energy autonomy are only possible if renewable energy (RE) resources are utilized. Sozen (2009, p. 4827) defines energy dependency as the extent to which an economy relies upon imports to meet its energy needs. The trajectory that a country follows from energy dependency to energy autonomy brings infrastructural, economic, geopolitical challenges from the social power perspective.

Michael Mann develops his theory on the sources of social power in four volumes written between 1986 and 2013. In these works, he takes the reader on a socio-spatial journey, investigating different sources of power throughout human history and suggesting that a general account of societies, their structure, and their history can best be given in terms of the interrelations of four sources of social power: ideological, eco- 
nomic, military, and political (IEMP) relationships (Mann, 1986, p. 2).

A starting point in transitioning to RE systems requires us to consider existing energy management structures and their respective histories. As briefly explained in Section 2 of this article, the Republic of Turkey followed steps similar to those presented in Mann's theory during the establishment of the republic and the formation of a centralised government through its Kemalist ideologies. Later on, the country built upon its national institutions by developing soft geopolitical networks. The military power did not have priority in the early years of the republic.

Therefore, the transition to RE systems was initiated with a centralised approach and formed around an infrastructural power. The social roots of state power had to be preserved, but an energy transition initiated at the same time. The socio-spatial context presented a challenge for existing institutional and regulatory structures in preparing to transition to RE systems. The liberalization of the electricity market had been initiated. The unbundling and privatization of utility companies were taking part both in the liberalization process but also paving the way for new investors. In other terms, it was presenting an overlapping interest for both government (and its institutions) and the new utility company investors as well as private investors.

It is the geographical location of Turkey that has, throughout history, prompted its governments to take geostrategic decisions. When the Republic of Turkey was established in 1923 with 378 deputies by Mustafa Kemal, a republican and secular constitution was adopted. Ankara was selected as capital at the centre of the country. As Kili (1980) has noted:

The immediate objective of the Kemalist reforms and the ideology of Kemalism was the realization of a Modern Turkish state and society. Their ultimate objective was bringing Turkey to a level even above contemporary civilization. The Kemalist principles of republicanism, nationalism, populism, secularism, étaism [statism], and devrimcilik (inkilapcilik) [revolutionism, (reformism)], were to provide the attainment of these objectives. (p. 387)

It is this reformist ideology that has prepared the ground for many geostrategic decisions at the national and international levels. As a result, starting from 1945, Turkey has participated in the United Nations, and has since joined the North Atlantic Treaty Organization (NATO), the Central Treaty Organization, the World Bank, the Organization for Economic Co-Operation and Development (OECD), the G-20 as well as regional organizations such as Organization for Security and Co-Operation in Europe (OSCE), the Organization of the Black Sea Economic Co-Operation (BSEC), the Organization for Islamic CoOperation (IOC), and made an application to become a member of the European Union (EU). These member- ships have provided a worldwide network and consolidated Turkey's geostrategic relevance in world affairs.

\subsection{History of the EU Membership Application and Contribution to Energy Reforms}

The lengthy accession process of Turkey into the EU started with its membership to the Council of Europe in 1950 as the 13th Member State. In 1959, Turkey applied for membership to the European Economic Community (succeeded by the EU). The Ankara Agreement was signed in 1963, establishing a plan for the development of a shared customs union. In 1993, negotiations between Turkey and the EU began, and the Customs Union took effect in 1996. This gave Turkey a strategic position by allowing for the free movement of goods and excluding agricultural products by eliminating the customs duties and charges (Delegation of EU to Turkey, 1995). In 1987, Turkey submitted a formal application for full membership to the EU. The European Council gave Turkey the status of candidate country in 1999 at the Helsinki Summit, marking the beginning of the accession negotiations (Delegation of EU to Turkey, n.d.).

The Turkish government application to becoming an EU member state has prompted many chapters of negotiation, including Chapter 15 which focuses mainly on the internal energy market, energy efficiency, RE resources, nuclear safety, radiation protection and security of supply. The development of RE policies were encouraged by the EU. Especially, the National RE Action Plan published in 2015 that has the characteristics of a roadmap was prepared in accordance with the EU directive 2009/28/EC (Ministry of Foreign Affairs-Directorate of EU Affairs, 2020).

\subsection{Structure of the Government}

While Turkey has been continuing its path for membership in European and worldwide organizations, its population reached to $82,886,421$ in 2019 . It is expected to be 100 million by 2040 (Turkish Statistical Institute, 2018), holding an average age of 32 by the end of 2018. This population has been governed by a secular, unitary, formerly a parliamentary republic which adopted a presidential system by referendum in 2017 (International Business Publications, 2018). This referendum proposed a set of 18 amendments to the constitution of Turkey (International Business Publications, 2018). The new presidency became an executive post with broad executive powers, abolishing the post of the prime minister. It has also called for changes to the Supreme Board of Judges and Prosecutors (International Business Publications, 2018). Another amendment resulted in an increase from 550 to 600 parliamentary deputies, representing 81 provinces and a landmass of over $783,562 \mathrm{~km}^{2}$.

The new powers given to the president included the right to issue decrees, propose the budget, appoint cabinet ministers and high-level bureaucrats with- 
out a confidence vote from the parliament, and directly and indirectly appoint the Council of Judges and Prosecutors (Kirisci \& Toygur, 2019, p. 5). These constitutional changes created concerns in the Parliamentary Assembly of the Council of Europe (Kirisci \& Toygur, 2019). Beside these concerns, a distinct economic impact was discernible. Although European Commission (2019) stated that the Turkish economy fell into recession in 2018 , a total of $0.9 \%$ of economic growth was reached by the end of 2019 (Turkish Statistical Institute, 2020). The government of Turkey announced the growth forecast as $5 \%$ for 2020 at the Official Gazette as part of the Annual Program of the Presidency.

\subsection{Argumentation}

Mann (1986, p. 13) defined society as a network of social interactions at the boundaries of which is a certain level of interaction cleavage between it and its environment. In the same volume, Mann (1986, p. 14) states that human beings are social but not societal-they need to enter into social power relations, but they do not need social totalities. Furthermore, in the fourth volume, he explains power as the capacity to get others to do things they otherwise would not do; that people would enter into power relations involving both cooperation and conflict with other people in order to achieve their goals (Mann, 2013, p. 1). Therefore, according to Mann (2013, p. 1) power may be collective, embodying cooperation to achieve shared goals-power through others-and distributive, wielded by some over others. Moreover, power may be authoritative or diffuse as well as extensive or intensive (Mann, 2012b, p. 6).

According to Mann's definition (2013, p. 1), ideological power derives from the human need to find ultimate meaning in life, to share norms and values, and to practice in aesthetic and ritual practices with others. Nevertheless, Mann (1986, p. 23) states that ideological organization first arises in a more autonomous form that is socio-spatially transcendent and it reaches in this way beyond the existing institutions of ideological, economic, military and political power. Finally, Mann (2012b, p. 7) concludes that institutionalized ideologies indicate a minimal presence of autonomous ideological power.

Mann (2012b, p. 9) defines economic power as the power that derives from the human need to extract, transform, distribute, and consume the produce of nature. Furthermore, he emphasizes that economic relations are powerful because they combine the intensive mobilization of labour with extensive circuits of capital, trade, and production chains, providing a combination of intensive and extensive power and, in most cases, of authoritative and diffused power (Mann, 2012b, p. 9). In the fourth volume, Mann (2013, p. 2) argues that the main organization of economic power in modern times has been industrial capitalism, a system allowing for the formation of markets into four main categories-capital, labour, production and consumption.
Mann (2012b, p. 11) resumes the definition of military power as the social organization of concentrated and lethal violence. It is a type of violence that is mobilized and focused (concentrated) as well as deadly (lethal; Mann, 2012b, p. 11). This form of violence is explained as having both intensive and extensive aspects, as well as the organization of defence and offense in large geographical and social spaces (Mann, 1986, p. 25).

Mann (2012b, p. 12) defines political power as centralised and territorial regulation of social life and the basic function of government as the provision of order over this realm. Mann (1986, p. 27) emphasizes that political power heightens boundaries, whereas other power sources may transcend them and can be involved in any social relationships where they are located. Furthermore, he discusses the despotic and the infrastructural powers of the state (Mann, 2012b, p. 13, 15) and he also states that states project military and political power externally, under the name geopolitics. Mann (2012b, p. 15) differentiates between hard geopolitics which involve war and soft geopolitics which involve political agreements concerning non-lethal matters like, law, economy, health, education, the environment, and so forth.

This approach is seen as an appropriate means for disentangling the complex socio-spatial context of interrelated and overlapping environments, economies and institutions in which RE systems exist. Its application will allow our case to be analysed in respect to the four sources of power that shape human society (Mann, 2013) and to emphasize the ability of human beings to pursue diverse goals and establish new networks of social interaction (Mann, 1986). Furthermore, it will provide insight into when the establishment of new systems (such as RE systems) to attain ideological, economic, military and political power will result in the formation of different network relations.

Turkey's vision and strategy for transition was informed by the following question: "How to achieve this transition for the benefit of all social actors within the RE systems?" Multiple win situations were considered to promote and expand RE systems, but the regulatory framework and electricity market were not ready for such a RE transition. The institutional structure and stateowned enterprises were also not instilling confidence in private investors, especially international investors who could provide the necessary capital to develop the energy sector. The bundling of electricity utilities was not creating an easy process for the realization of future projects. Therefore, unbundling and privatization activities allowed for new ways of doing business and a more balanced sharing of power between the state and other energy market actors and creating new intersecting networks of relations for RE stakeholders.

The transition has played an important role within the energy strategies of the government and that it provides a solution to the key challenges of a growing economy in a developing country. It enhances the security of supply, decreases import dependency, and increases 
the share if low-carbon energy solutions in the energy mix. Due to Turkey's geostrategic history with its central and unitary state, the RE transition legislation followed a similar centralised path. However, it has incorporated private and public investments by supporting the transition with parallel activities such as electricity market reforms and liberalization. These new steps have always been supported by the political parties in government or those in opposition because they bring new sources of income and jobs for the economy, the investors and the people they are representing.

Other energy reforms took place before the 2015 National RE Action Plan. The first phase in the 1980's and 1990's facilitated a transition from state ownership and control toward a liberal market economy, followed by energy sector restructuring and private sector participation in the power sector (World Bank, 2015, pp. 19-20). Since 2001, the second phase of market-based reforms involved electricity market development, as well as the legal, regulatory, institutional framework. It re-structured state-owned power companies, took transitional measures, placed unbundling of functions, and included provisions for open access to transmission and distribution grids. Furthermore, it created eligible consumers and market openness, centralised balancing, settlement, and trading arrangements, and furthered the development of trading platforms and privatization (World Bank, 2015, pp. 22-26).

This article analyses the geostrategic RE transition of the Republic of Turkey in light of the four sources of social power analysed by Michael Mann. Through the analysis of the socio-spatial relations between ideological, economic, military and political powers, it seeks to understand the transition from a fully centralised energy management perspective towards a partially centralised management model through the unbundling of its utility companies. It begins by briefly reviewing Turkey's current geographical, governmental, and demographic situation with the history of the Republic of Turkey to reflect on the reasons of the current RE development strategy. It analyses the four sources of social power as described by Mann in 1986, 2006, 2012, and 2013. Section 2 describes the unbundling and the privatization of the public electricity companies toward an open electricity market. It investigates and analyses the recent history of RE from an organizational perspective. Section 3 discusses the RE transition strategy and related legislation. Section 4 explains the impact of the unbundling on the development of the RE projects from 2008 until 2018. It investigates the development in the RE systems by comparing the data on the RE installed power plant capacity and its contribution to the energy sector. Moreover, it analyses closely the solar power plant and wind power plant projects' development over time, during the course of the legislative and regulatory development. Section 5 discusses the results of the statistical data derived from Electricity Transmission Company of Turkey (TEIAS) and Section 6 concludes with reflections on the implications of centralised versus decentralised RE project management.

\section{Unbundling and Privatization}

Mann (2012b, p. 6) reflects on the four sources of social power as the organizational means by which we can efficiently attain our varied goals. In order to achieve these goals and meet the energy needs of the country, a series of restructuring and privatization measures (World Bank, 2015) took place. The Turkish Electricity Authority (TEK) established in the 1970s, and active in Turkey's electricity generation, transmission and distribution, was first split into Electricity Generation and Transmission Company (TEAS) and Electricity Distribution Company (TEDAS) 1994. Later on, TEDAS was unbundled and privatized to reach efficient electricity market operations. From the economic power perspective, TEK was the only handler of this need to extract, transform, distribute the produce of nature as explained in the Section 1.3.

The foreseen value of industrialized capitalism, which is the economic power of modern times, had an intersecting and overlapping interest with both political power (central, institutionalized and diffuse) and ideological power (liberalization). The increased trade of capital, labour, production and consumption was enabled by the unbundling and privatization of the electricity market. For the governing power, this presented a way of attracting foreign investment, encouraging domestic investment and attaining further financial resources while contributing to the energy needs of the country.

This is how, over the course of the electricity market restructuring, new actors appeared. The Energy Market Regulatory Authority (EMRA) was established in 2001 to regulate generation and transmission related activities. The TEAS was unbundled into the Electricity Generation Company of Turkey (EUAS) and the TEIAS. The Electricity Trading and Contracting Corporation of Turkey (TETAS) became the manager of sovereignguaranteed power purchase agreements and sales to uncreditworthy electricity distribution companies (Deloitte, 2016, pp. 18-19).

One of the biggest steps in this transition was the privatization of the regional distribution activities of TEDAS, resulting with its unbundling into 21 zones-with 21 different private distribution companies-from 2004 to 2013. As the 2015 World Bank report Turkey's Energy Transition suggests, privatizing distribution was prioritized to create confidence in prospective investors and facilitate further privatizations and capacity expansion. Nevertheless, TEDAS has retained its regional headquarter for monitoring and supervision purposes.

Mann (2012b, p. 9) quoted what Schumpeter (1942) famously called "creative destruction," whereby growth occurs through the destruction of old industries and organizational forms and through the creation of new ones. This destruction and creation of new structures (Figure 1) in the energy market enabled the introduction 


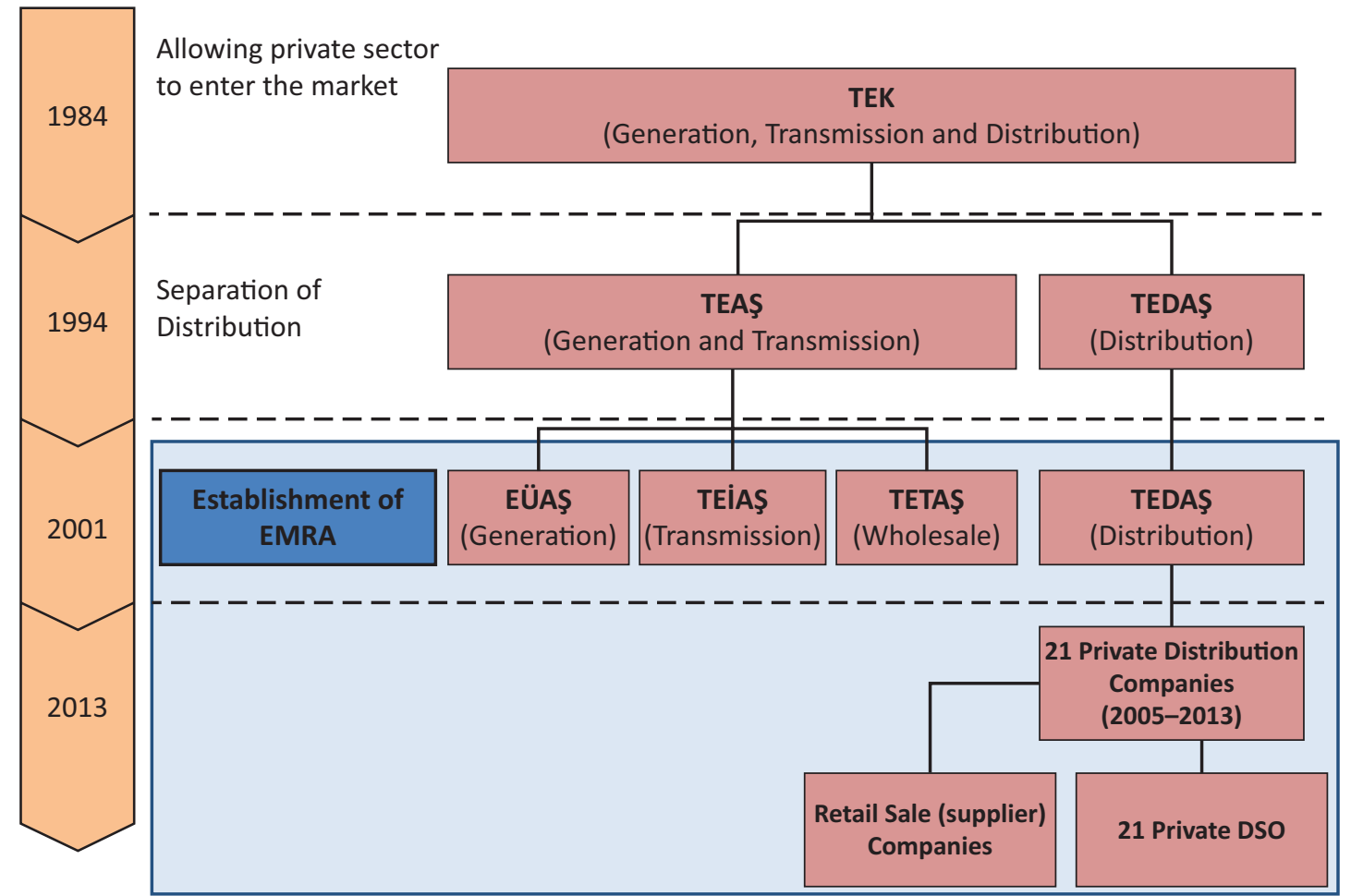

Figure 1. The general structure of the existing electricity sector in Turkey. Source: International Atomic Energy Agency (2018).

of renewable electricity generation by private companies and individuals to be fed into the grid. Beginning with one big state-owned company, twenty-five companiesboth state and private-were born. The structural breakdown of one powerful central unit of generation, transmission and distribution has not resulted in the loss of power. Instead, it has created a different model of management, with different energy market actors, without losing the state's control over the energy management of the country.

TETAS, handling the electricity trade and wholesale activities, used BOO (Build-Own-Operate), BOT (BuildOperate-Transfer) and TOOR (Transfer-of-OperatingRights) models with private companies. In addition, industries were allowed to generate electricity for their own needs and named after auto-producers.

Followed by the unbundling in the electricity market along with the privatization of the utility companies, privatization continued to accelerate. Figure 2 illustrates the change in the ratio of the public versus private ownership of the installed capacity. In 2008, the installed electricity generation capacity in the public sector was $58 \%$ versus $42 \%$ in the private sector. A breakeven point was reached in 2010 and by the end of 2018, the private sector owned $79.1 \%$ of the total installed capacity, with the public sector retaining only $20.9 \%$.

In the geostrategic RE transition path that the Republic of Turkey has chosen to pursue, the liberalization of the Turkish electricity market, the establishment of the necessary market actors and the privatization have built trust for both investors and consumers. Still, TEDAS has not lost relevance and has instead changed its operational structure to enhance RE projects at different scales. Thus, the institutional and organizational power of the state were not dissolved but changed their position through the unbundling of the utility companies. A remarkable point from 2008 until now, is that there was no change in political power. This was one of the reasons why there are lot of interest from both national and international investors along with state and non-state actors in the RE business. A desirable growth in RE investments was reached in 2019 which fostered sectoral and regional economic development. This demonstrates the role that carefully designed, planned and implemented social power actions can have within a successful RE management framework.

\section{Renewable Energy: From Strategy to Legislation}

The Turkish government has structured its main energy strategies to focus on the following priorities: 1) promoting activities to enhance energy supply security; 2) giving due consideration to environmental concerns throughout the energy chain; 3) increasing efficiency and productivity, establishing transparent and competitive market conditions through reform and liberalization; 4) augmenting research and development of energy technologies, and increasing the ratio of local RE in the energy mix, to increase energy efficiency and diversify supply routes and sources for imported oil and natural gas; and 5) to add nuclear energy to the energy mix (Ministry of Foreign Affairs, n.d.). 


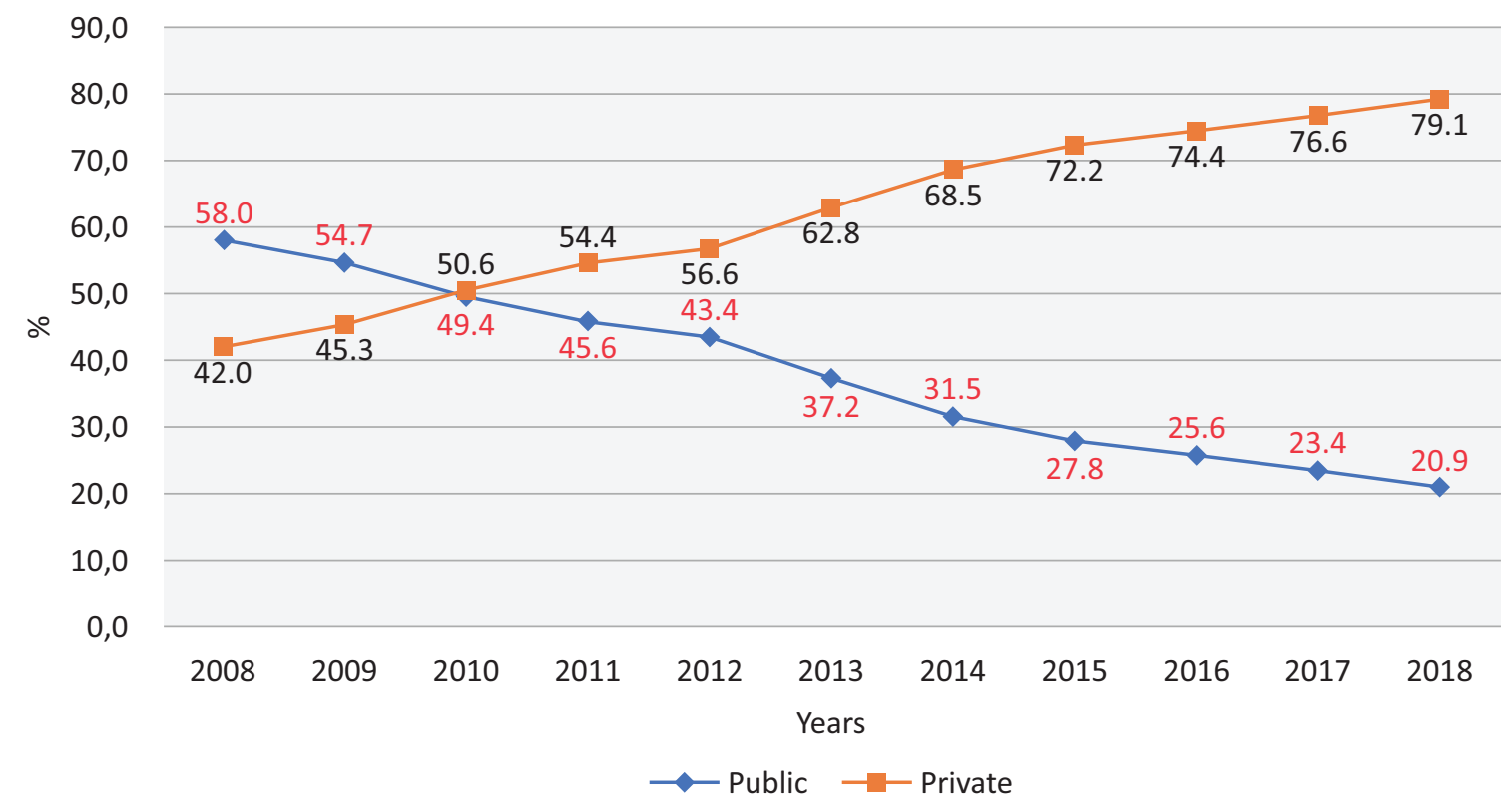

Figure 2. The distribution of Turkey's installed capacity by the public and private sectors (2008-2018). Source: TEIAS (2018).

Geographically rich in natural resources, centralised energy institutions and political structure, in 2009 the country set the goal of meeting $30 \%$ renewables by 2023 , building on the RE policies which were being developed since the enactment of the Electricity Market Law (EML) in 2001. One noteworthy step was the introduction of prosumers to the electricity market, allowing individuals to act as both RE producers and consumers. The Law on Utilization of Renewables in Electricity Generation No.5346 was passed in 2005, twice-amended and followed by the Energy Efficiency Law No.5627 (Deloitte, 2014, pp. 18-19). The aim of these laws was to support the use of RE resources in order to contribute to the diversification of energy resources, to reduce greenhouse gas emissions and to protect the environment (World Bank, 2015) as well as to develop related manufacturing sector to realize these objectives.

The RE Support Mechanism and unlicensed energy generation regulations were introduced in 2011, allowing for the unlicensed electricity generation from renewable resources of up to $500 \mathrm{~kW}$. Additional feed-intariff support for locally manufactured components was added in 2013 for unlicensed electricity generation. The government has acted with precaution in the development of the capacity of RE projects. Unlicensed project capacities were initially capped at $500 \mathrm{~kW}$ in 2011 . This was increased to $1 \mathrm{MW}$ in 2013 and finally to $5 \mathrm{MW}$ in 2019 under certain conditions. The feed-in-tariff for electricity production from RE sources was guaranteed for 10 years for unlicensed projects. Licensed projects were obliged to follow a competitive tender process for allocated lands in different regions of Turkey.

Beginning in the 1980's, public utilities were privatized and changed their operational models to promote the use of renewables. The utilities were divided in six categories, as seen in Figure 3: (1) Independent Power
Producers (IPP), (2) BOT, (3) BOO, (4) TOOR, (5) Energy Production AS (EÜAS) and (6) unlicensed private owners. In 2018, Turkey's total installed capacity reached $88,550.8 \mathrm{MW}$, with each type of utility maintaining its own stake in thermal, hydro, geothermal, wind, and solar energy capacities. Furthermore, within this energy mix, the unlicensed portion represents $6 \%$ of total installed capacity in 2018 (5,352.4 MW), made possible by changes in the regulation of renewables, namely hydro, wind and solar power plants which are up to $1 \mathrm{MW}$ of capacity each.

This ratio of $6 \%$ of installed capacity, growing over 13 years, shows the willingness of the private sector to contribute to energy generation when a stable/guaranteed support mechanism is established, in this case feed-in-tariffs. In other words, the changes in the institutional structures, and the integration of an economic value system with the feed-in-tariffs, have led to the establishment of RE sources' economic power by creating an inter-relation with the rest of sources of social power such as ideological and political. Consequently, a win-win situation has been created within a given geography where the electricity beneficiary is the end-user, the institutions monitor the security of supply and planning, and private sector/contractors trade on a liberalized energy market. The economic power (industrial capitalism) chain has successfully been created.

\section{Development of Renewable Energy Projects with New Policies}

As outlined above, institutional changes to create a liberalized market and fulfil energy demands had a dramatic effect on Turkey's RE sector. The annual development of total renewable installed capacity excluding hydro from 2000 until 2018 has been shown in the Table 1. 


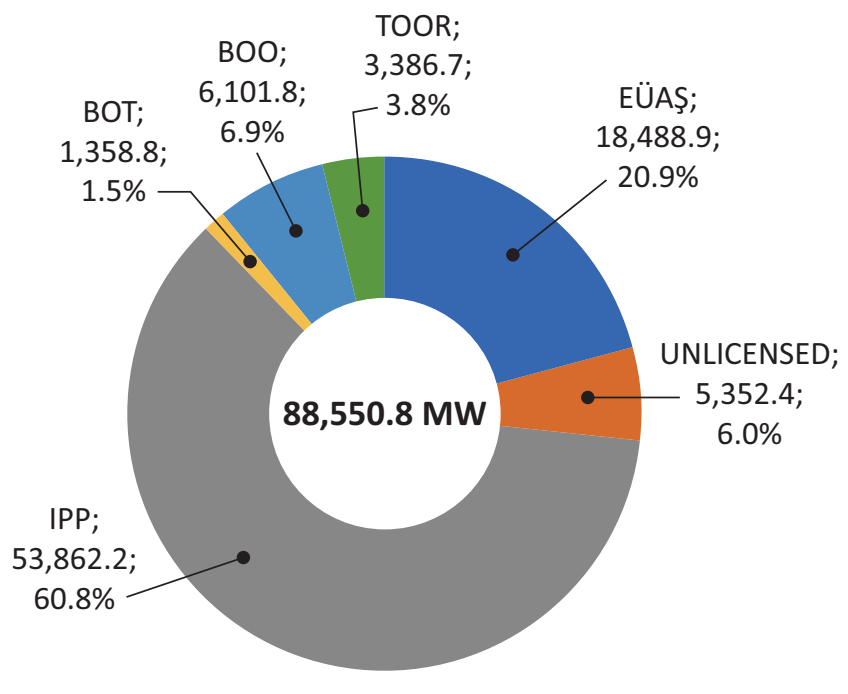

EÜAŞ $\square$ UNLICENSED $\square$ IPP $\square$ BOT $\square$ BOO $\square$ TOOR

Figure 3. The distribution of Turkey's installed capacity by the electricity utilities in 2018. Source: TEIAS (2018).

Although 28,291.40 MW hydro from the overall capacity of $88,550.80 \mathrm{MW}$ are accounted under the RE category, there is a debate about their sustainability in different geographical regions of the country and moreover, the development of hydro power plants have followed a different set of policies that were developed prior to RE policy. As such, this article will focus only on the increase of wind and solar energy projects since the passing of the 2005 law on RE policy (Law No.5346 on the use of RE resources for generation of electricity).

Although grid-connected solar photovoltaic (PV) power plants were not very widespread in 2011 when the feed-in-tariff based support scheme was first introduced, they have become one of the fastest developing RE types in Turkey (Energy Market Regulatory Authority, 2011). This was facilitated in part by the government price guarantee of 0.133 USD per kWh of generated solar electricity. As an additional support mechanism, producers utilizing local materials are provided with an additional 0.067 USD per kWh, equalling a total sum of 0.20 USD per kWh under optimal conditions. This support scheme acted as an economic power stimulant and added value to local investment, labour and products. When the ambitious involvement of the solar energy

Table 1. Annual development of RE based installed capacity share in Turkey total installed capacity (2000-2018).

\begin{tabular}{|c|c|c|c|c|c|c|c|c|}
\hline Years & Hydro & Geothermal & Wind & Solar & Biomass * & $\begin{array}{c}\text { Renewable } \\
\text { Installed Capacity }\end{array}$ & $\begin{array}{c}\text { Total } \\
\text { Installed Capacity }\end{array}$ & $\begin{array}{c}\text { Renewable } \\
\text { Share \% }\end{array}$ \\
\hline 2000 & $11,175.2$ & 17.5 & 18.9 & & 10.0 & $11,221.6$ & $27,264.1$ & 41.2 \\
\hline 2001 & $11,672.9$ & 17.5 & 18.9 & & 10.0 & $11,719.3$ & $28,332.4$ & 41.4 \\
\hline 2002 & $12,240.9$ & 17.5 & 18.9 & & 13.8 & $12,291.1$ & $31,845.8$ & 38.6 \\
\hline 2003 & $12,578.7$ & 15.0 & 18.9 & & 13.8 & $12,626.4$ & $35,587.0$ & 35.5 \\
\hline 2004 & $12,645.4$ & 15.0 & 18.9 & & 13.8 & $12,693.1$ & $36,824.0$ & 34.5 \\
\hline 2005 & $12,906.1$ & 15.0 & 20.1 & & 13.8 & $12,955.0$ & $38,843.5$ & 33.4 \\
\hline 2006 & $13,062.7$ & 23.0 & 59.0 & & 19.8 & $13,164.4$ & $40,564.8$ & 32.5 \\
\hline 2007 & $13,394.9$ & 23.0 & 147.5 & & 21.2 & $13,586.6$ & $40,835.7$ & 33.3 \\
\hline 2008 & $13,828.7$ & 29.8 & 363.7 & & 38.2 & $14,260.4$ & $41,817.2$ & 34.1 \\
\hline 2009 & $14,553.3$ & 77.2 & 791.6 & & 65.0 & $15,487.1$ & $44,761.2$ & 34.6 \\
\hline 2010 & $15,831.2$ & 94.2 & $1,320.2$ & & 85.7 & $17,331.3$ & $49,524.1$ & 35.0 \\
\hline 2011 & $17,137.1$ & 114.2 & $1,728.7$ & & 104.2 & $19,084.2$ & $52,911.1$ & 36.1 \\
\hline 2012 & $19,609.4$ & 162.2 & $2,260.6$ & & 147.3 & $22,179.5$ & $57,059.4$ & 38.9 \\
\hline 2013 & $22,289.0$ & 310.8 & $2,759.7$ & & 178.0 & $25,537.5$ & $64,007.5$ & 39.9 \\
\hline 2014 & $23,643.2$ & 404.9 & $3,629.7$ & 40.2 & 227.0 & $27,945.0$ & $69,519.8$ & 40.2 \\
\hline 2015 & $25,867.8$ & 623.9 & $4,503.2$ & 248.8 & 277.1 & $31,520.8$ & $73,146.7$ & 43.1 \\
\hline 2016 & $26,681.1$ & 820.9 & $5,751.3$ & 832.5 & 363.8 & $34,449.6$ & $78,497.4$ & 43.9 \\
\hline 2017 & 27,273.1 & $1,063.7$ & $6,516.2$ & $3,420.7$ & 477.4 & $38,751.1$ & $85,200.0$ & 45.5 \\
\hline 2018 & $28,291.4$ & $1,282.5$ & $7,005.4$ & $5,062.8$ & 621.9 & $42,264.0$ & $88,550.8$ & 47.7 \\
\hline
\end{tabular}

Notes: *Includes Industrial Waste; Unit: MW. Source: TEIAS (2018). 
investors and prosumers met with the existing transmission and distribution line infrastructures, the institutional structures were not ready to cope with this demand. A few more years were needed to settle associated administrative changes. Neglecting the installations made in 2012 and 2013, the installed solar PV capacity accounted 40.2 MW in 2014 and over 5,000 MW in 2018.

Within five years of the scheme being introduced solar production capacity in Turkey increased by around $12,500 \%$, with licensed and unlicensed projects from the land-based or rooftop solar PV systems feeding into the grid. Open to both private or public sector, unlicensed projects followed a determined permission process by submitting required documents and/or permits from the Ministry of Environment and Urbanism, the Ministry of Energy and Natural Resources, and the Ministry of Agriculture on its case. Several reports, documents and calculations had to be approved by the civil engineers, electrical engineers, and geology engineers to the utility company in the region and/or to TEDAS. This permission process itself was already showing how the state was not giving away its institutional and organizational power. Privatization could make certain processes easier however it was not entirely meaning a true power shift. Furthermore, another striking result is illustrated in Table 2 with the capacity of the unlicensed solar PV projects applied to the authorities totalling 21,592.41
MW in 2017. An additional 14,186.95 MW was rejected by the authorities.

From a spatial perspective, 21,592.41 MW implies approximately $43,184.82$ ha of land belonging to at least 21,592 people or to companies who have a land ownership located outside of the urban areas. This constitutes the land in the periphery which is not suitable for agriculture but was accepted for RE installations. Different financing scenarios have been developed for these spaces both for investors and/or for the land owners which resulted in the high number of applications.

This expansion in solar PV projects clearly shows how the use of social power mechanisms can result in multiple win scenarios. The state institutions' benefit has been the generation of electricity generated from RE sources which reduces dependence on energy imports, reduced carbon emissions and creates investment and employment opportunities. This system allows both national and international investors to generate income and energy in this booming sector. At the same time, prosumers are given the opportunity to off-set their consumption while increasing income.

Many wind power plants were established by individual initiative before the RE law was passed. The first wind power plant was built in 1998 in a village in the Izmir province, a region with some of the highest potential for wind power in Turkey. By the time the RE reform

Table 2. The status of unlicensed electricity generation applications by the end of 2017.

\begin{tabular}{|c|c|c|c|c|c|c|c|c|c|c|c|}
\hline Status & Stream & Biomass & Multifuel & Wave & $\begin{array}{c}\text { Natural } \\
\text { Gas }\end{array}$ & $\begin{array}{l}\text { Solar } \\
\text { (PV) }\end{array}$ & $\begin{array}{l}\text { Solar } \\
\text { (CSP) }\end{array}$ & Hydro & $\begin{array}{l}\text { Geo- } \\
\text { thermal }\end{array}$ & Wind & Total \\
\hline $\begin{array}{l}\text { Application } \\
\text { period for } \\
\text { connection } \\
\text { agreement } \\
\text { has expired }\end{array}$ & & 13.44 & & & 20.33 & 593.93 & & 2.21 & & 37.57 & 667.47 \\
\hline $\begin{array}{l}\text { Connection } \\
\text { agreement } \\
\text { done }\end{array}$ & & 17.90 & 16.92 & & 77.91 & $3,026.43$ & & 12.38 & & 77.73 & $3,229.27$ \\
\hline $\begin{array}{l}\text { Connection } \\
\text { agreement } \\
\text { expired }\end{array}$ & & 1.56 & & & 5.05 & 123.26 & & & & 2.20 & 132.07 \\
\hline $\begin{array}{l}\text { Under } \\
\text { evaluation }\end{array}$ & & 28.57 & 6.00 & & 10.41 & 134.57 & & & & 1.00 & 180.56 \\
\hline $\begin{array}{l}\text { Installed \& } \\
\text { Activated }\end{array}$ & & 66.72 & 2.40 & & 8348 & $2,978.84$ & 1.00 & 8.69 & & 32.20 & $3,173.32$ \\
\hline Accepted & & 49.38 & 2.67 & & 52.04 & 548.43 & 0.08 & 7.57 & 5.57 & 79.44 & 745.17 \\
\hline Rejected & 0.50 & 148.49 & 11.45 & 0.40 & 71.62 & $14,186.95$ & & 47.77 & & 334.26 & $14,801.44$ \\
\hline Total & 0.50 & 326.06 & 39.44 & 0.40 & 320.84 & $21,592.41$ & 1.08 & 78.62 & 5.57 & 564.4 & $22,929.30$ \\
\hline
\end{tabular}

Note: Unit: MW. Source: EMRA (2018). 
was passed in 2005, Turkey's installed wind power plant (WPP) capacity totalled 20.1 MW. As shown in Table 1, this capacity reached $1,728.70 \mathrm{MW}$ in 2011. It further increased to 3,629.70 in 2014 and 7,005.4 MW in 2018 after the announcement of the feed-in-tariffs (Table 1). Similar to solar energy projects, the first project implementations always took longer. Accordingly, the installed capacity has increased drastically in the recent years. In contrary to solar energy projects, however, the majority of wind power plant capacity has belonged to licensed projects. By the end of 2016, the unlicensed commissioned projects were $10.4 \mathrm{MW}$ and permitted but under construction WPP resulted in 81.7 further MW. Once more the impact of secure financial support mechanisms, a stable economy and clear permission procedures is clearly demonstrated in the rapid growth of Turkey's WPP capacity.

An overall assessment of the RE ratio may be derived from Table 1 . The RE-based installed capacity is $15.8 \%$ of the overall installed capacity by the end of 2018, as compared to the goal of $30 \%$ by 2023 (without taking into account hydro capacity which might mislead). With 2023 the centenary of the Republic of Turkey, the ambitious goals are to reach 20,000 MW WPP (Deloitte, 2016) capacity and 15,000 MW solar capacity (as announced in the press release by the president of the Turkish Solar Energy Industry Association on 14th January 2020; GENSED, 2020). Whether these goals are realistic is a matter of ongoing discussion. The potential for the rapid growth of the RE sector in Turkey has, in any case, already been demonstrated.

\section{Discussion: Centralization vs. Decentralization and Energy Autonomy}

RE systems act as a tool because the development and growth of a country is directly related to its energy administration. Depending on their interest and social power relations, countries may use this power/energy whether as a tool for economic development, by attracting investment and financial income, or as a developmentoriented tool to create energy autonomy, energy justice and rural development in a sustainable way.

The integration of RE systems within a centralised system or a completely energy autonomous decentralised system will always be dependent on the given sociospatial conditions. RE systems incorporate environmental, technological, economic and socio-spatial aspects and link central and peripheral spaces through sociotechnical practices in an environmentally friendly way. Prosumers directly consume what they generate, they off-set their energy consumption and sell the extra energy to the grid. Electricity which is generated from renewable resources in peripheral and marginal land may be connected to the national grid network which contributes to grid stability.

This article discussed the centralization and decentralization of RE systems from the territorial perspective of the nation-state. If one should seek to develop and implement a completely energy autonomous system in an existing electricity grid infrastructure, a financial source is needed to buy the equipment and install the system. This presents an intensive economic power. If this financial source is unavailable, moving to energy autonomous scenario is not realistic. However, if this financial source is missing, there may still be a potential way to introduce the RE systems by using political and governmental power in a diffuse way and utilizing socio-spatially transcendent ideologies. This situation may present itself in the form of industrial capitalism with global actors. Nevertheless, this system can only work if the social connectedness and the exchange of power networks in various forms among market actors is well-facilitated. This is the reason why Mann's social power approach explains the dynamics behind the RE systems.

Sovacool (2016, p. 202) stated that transitioning to newer or cleaner energy systems (such as RE) requires shifts not only in technology but also in political regulations, tariffs and pricing regimes and the behaviour of users and adopters. The recent RE transition history of Turkey discussed in this article depicts a transition in a centralised system within a strategic geography. The preparation of the energy market, market actors, necessary strategies and legislation were the key components and a strong base for the implementation of RE projects. However, the capacity of the institutions, the capacity and improvement of the existing transmission and distribution infrastructure needed to be upgraded in order to meet the demand as well.

Within this context of a country with a growing population and economy forecasted in the strategic and development plans, the social demand has been driven mainly by investment and electricity cost-reduction perspectives. From one side, the intention of the private investor was to generate income and energy by harnessing the power of the "free sun" and the "free wind." These investors have not been dissuaded by lengthy permitting or licensing processes which kept on changing along the implementation of the projects. On the other hand, the intention of the government behind the support of RE in Turkey has been the transition to low-carbon technologies, to reduce the import dependency on primary energy sources and to make a step in the energy autonomy by restructuring the centralised system. As Sovacool (2016, p. 202) clearly states, the speed at which a transition can take place-its timing, or temporal dynamicsis a vital element of consideration. And all energy transitions take time.

Indeed, it has taken time in the case of Turkey, from the energy-market preparation and planning phase of the 1980 's to the 2005 reform and subsequent RE sector expansion. Bayraktar (2018, p. 26) underlines that many of these ambitious plans prioritize securing energy supply, reducing the adverse economic impacts of increasing energy imports. They also make markets more competitive, and increase investments in RE. Nevertheless, al- 
though these liberalization and privatization events may seem promising, in between the lines, the authorities have always been the ones who retain power.

Undoubtedly, while both small/large scale gridconnected implementations were very popular, free sun brought some energy autonomy for some stand-alone system users. Inspired by the free primary energy resource, and with the introduction of the small-scale solar and wind systems in the Turkish market, stand-alone system users at home have benefited by receiving permission to meet their own energy needs, free from the grid and free from undue administrative burdens. They have become the first off-grid prosumers of Turkey, and they have not yet been quantified.

Instead of approaching two separate concrete paths as centralised or decentralised transitions, where an entire energy system and/or institutional structure needs to be revised accordingly, partially managed models could provide faster transitions to RE and enable practical solutions for people. Zuidema and de Roo (2015, p. 71) state that decentralization in urban areas makes municipalities responsible for developing their own environmental policies and to strategically position environmental interests in integrated local policies. Accordingly, such strategic and cross-sectoral working requires competences such as visionary thinking, communicative skills and strategic planning (Zuidema \& de Roo, 2015, p. 13). In either type of management system, there exists a degree of responsibility for the continuity of the system and this does not differ much between urban and rural areas. A decentralised transition with any level of government involvement may be seen as a kind of hybrid form or pseudo-decentralization due to its connection to the institutionalised power source. Indeed, whether an absolute decentralization, an island model, is possible or not within the existing governmental and social structures, their individual as well as their collective power is debatable.

\section{Conclusion}

Michael Mann's The Sources of Social Power was translated and published in Turkish in 2012 as iktidarin tarihi (Mann, 2012a), meaning the history of the governing power. It clearly explains how, through the use of the combination of these social power sources and their interrelations and intersections, a greater benefit occurs for the governing power. In fact, the overlapping points occurring in this RE transition create a socio-spatial intensity necessitating regulatory means. The intersection of these regulatory means in different organizational networks define the nature of its centralised or decentralised power structures.

More than a decade now, with the latest changes in its energy policies, Turkey's precautionary, partiallyliberalised RE landscape paints a promising portrait in this specific geographical, political and institutional space, while demonstrating the power of a centralised government and the role of the state. In this case, the centralised management model in a liberal electricity market represents a grid-connected, feed-in-tariff incentivised RE management transition model in a developing country. From this, an appropriate management or selforganisation model may be derived for the decentralised electricity transition in other places. Indeed, from a technical perspective, a centralised grid-connected energy system is a combination/connection of many decentralised energy systems into a grid. What this means in practice: Depending on the countries' or regions' or governments' sources of social power as discussed in this article, a different model of RE transition with different layers of liberalization or privatization or self-organisation is also possible. This could in some cases facilitate a faster $\mathrm{RE}$ transition than purely centralised or decentralised process options.

Moreover, given the institutional structure and economic drivers, RE transition can be seen as a political power tool. While the privatization of state-owned companies in general remains an issue, a national debate for several reasons in the country, the unbundling of the utility companies to improve the RE project developments in a wider scale has proven to be practical. The 2023 vision for RE in the energy mix was another tool to stimulate the infrastructural changes for the government and to encourage foreign investment in the country. Not only the government, but companies, and landowners have all profited in different ways. Nevertheless, the power remained intertwined in the lines of the permission and licensing processes, or under other contractual formats in spite of this unbundled scenario.

In terms of the geostrategic RE transition discussed in this article to contribute to the thematic issue on Governance and Politics of Electricity System Transitions, Turkey's transcontinental position does not allow the country's energy sector to be completely decentralised. The energy reforms necessary to better accommodate electricity generation from RE sources enabled private consumers. The unbundling and privatization of the utility companies, as well as the liberalization of the electricity market helped facilitate Turkey's innovative electricity market. This made Turkey an international hub for interconnected transmission systems between Europe, Asia and Middle East. The economic power in the form of industrial capitalism has been used in connection with political power to promote and expand RE projects. Perhaps, Turkey's approach in expanding the RE use in the energy mix does not represent a spectacular or unfamiliar form of encouragement by introducing feed-intariffs. Nor, is the privatization of state companies uncommon. Nevertheless, this geostrategic manoeuvre of the institutional and political power in high collaboration with economic power and the intertwined, overlapping characteristics within the socio-spatial context have resulted in the above-mentioned project successes and continue being promising for the future.

In conclusion, as it is described by Mann (2012b): 
The IEMP Model is not a social system, but rather an analytical tool form of an analytical point of entry for dealing with messy real societies where these four power sources offer distinct organizational networks and means for humans to pursue their goals. (p. 16)

In this way, the organisation of the (de)centralised electricity transitions are dependent on the history, geography and the overlapping relations of these sources of social power. Nevertheless, the answer to the question of who is prepared to take responsibility within the given country will determine how the social power will take place for the (renewable) energy transitions.

\section{Acknowledgments}

The author would like to thank to three anonymous reviewers for their constructive comments and the journal's editorial board for their support. The author is grateful to Prof. Dr. Eberhard Rothfuß and Dr. Festus Boamah for their encouragement and continuous support.

\section{Conflict of Interests}

The author declares no conflict of interests.

\section{References}

Bayraktar, A. (2018). Energy transition in Turkey. Turkish Policy Quarterly, 17(3), 19-26.

Delegation of the European Union to Turkey. (1995). Decision No 1/95 of the EC-Turkey Association Council of 22 December 1995 on implementing the final phase of the customs union (96/142/EC). Ankara: Delegation of the European Union to Turkey. Retrieved from https://www.avrupa.info.tr/sites/default/files/ 2016-09/Custom_Union_des_ENG_0.pdf

Deloitte. (2014). National renewable energy action plan for Turkey. Ankara: Ministry of Energy and Natural Resources. Retrieved from https://www.ebrd. com/documents/comms-and-bis/turkey-nationalrenewable-energy-action-plan.pdf

Deloitte. (2016). Turkish energy market outlook. London: World Energy Council. Retrieved from https:// www.dunyaenerji.org.tr/wp-content/uploads/ 2017/10/turkish-energy-market-outlook.pdf

Electricity Transmission Company of Turkey. (2019). Electricity production and consumption statistics. Electricity Transmission Company of Turkey. Retrieved from https://www.teias.gov.tr/tr/yayinlar-raporlar

Energy Market Regulatory Authority. (2018). Electricity market development report 2017. Ankara: Energy Market Regulatory Authority. Retrieved from https://erranet.org/wp-content/uploads/2016/11/ Electricity-Market-Development-Report-2017.pdf

Energy Market Regulatory Authority. (2011). Elektrik piyasasinda lisanssiz elektrik üretimine iliskin yönetmelik[Regulation on the unlicensed generation of electricity in the electricity market] (No.28001, 21.07.2011). Ankara: Official Gazette. Retrieved from https://www.resmigazete.gov.tr/eskiler/2011/ 07/20110721-7.htm

European Commission. (2019). Commission staff working document economic reform programme of Turkey (2019-2021). Commission Assessment (Report No. 164). Brussels: European Comission. Retrieved from https://ec.europa.eu/neighbourhoodenlargement/sites/near/files/turkey_2019-2021_ erp.pdf

GENSED. (2020). Basin Aciklamasi-14.01.2019 [Press Release-14.01.2019]. GENSED. Retrieved from https://www.gensed.org/basin/basin-aciklamasi14.01.2019

International Atomic Energy Agency. (2018). Turkey country profile. International Atomic Energy Agency. Retrieved from https://www-pub.iaea.org/ MTCD/Publications/PDF/cnpp2018/countryprofiles/ Turkey/Turkey.htm

International Business Publications. (2018). Turkey government system handbook. Washington, DC: International Business Publications.

Kili, S. (1980). Kemalism in contemporary Turkey. International Political Science Review/Revue Internationale De Science Politique, 1(3), 381-404. Retrieved from www.jstor.org/stable/1601123

Kirisci, K., \& Toygur, I. (2019). Turkey's new presidential system and a changing west. Washington, DC: The Brookings Institution. Retrieved from https:// www.brookings.edu/wp-content/uploads/2019/01/ 20190111_turkey_presidential_system.pdf

Mann, M. (1986). The sources of social power (Vol. 1). Cambridge: Cambridge University Press.

Mann, M. (2012a). Iktidarin tarihi, siniflar ve ulus devletlerin yükselisi [The sources of social power]. Ankara: Phoenix Yayinevi.

Mann, M. (2012b). The sources of social power (Vol. 3). Cambridge: Cambridge University Press.

Mann, M. (2013). The sources of social power (Vol. 4). Cambridge: Cambridge University Press.

Ministry of Foreign Affairs. (n.d.). Turkey's energy profile and strategy. Ministry of Foreign Affairs. Retrieved from http://www.mfa.gov.tr/turkeys-energystrategy.en.mfa

Ministry of Foreign Affairs-Directorate of EU Affairs. (2020). Chapter-15: European Union policy on energy. Ministry of Foreign Affairs-Directorate of EU Affairs. Retrieved from https://www.ab.gov.tr/_80_ en.html

Scheer, H. (2007). Energy autonomy. London: Earthscan.

Sovacool, K. B. (2016). How long will it take? Conceptualizing the temporal dynamics of energy transitions. Energy Research \& Social Science, 13, 202-215.

Sozen, A. (2009). Future projection of the energy dependency of Turkey using artificial neural network. Energy Policy, 37(11), 4827-4833. https://doi.org/ 10.1016/j.enpol.2009.06.040 
The Delegation of the European Union to Turkey. (n.d.). EU and Turkey's History. The Delegation of the European Union to Turkey. Retrieved from https://www. avrupa.info.tr/en/eu-and-turkeys-history-711

Turkish Statistical Institute. (2018). Population by years (2018-2020). Turkish Statistical Institute. Retrieved from http://www.tuik.gov.tr/UstMenu.do? metod=temelist

Turkish Statistical Institute. (2020). Haber bülteni 28.02.2020, Dönemsel gayrisafi yurt ici hasila, IV.ceyrek: Ekim-Aralik 2019 [Press Release 28.02.2020, Periodic gross domestic product, Quarter 4: October-December 2019]. Turkish Statistical
Institute. Retrieved from http://www.tuik.gov.tr/Pre HaberBultenleri.do?id=33603

World Bank. (2015). Turkey's energy transition (Report No. ACS14951). Washington, DC: World Bank. Retrieved from http://documents.worldbank.org/ curated/en/249831468189270397/pdf/ACS14951REVISED-Box393232B-PUBLIC-EnergyVeryFinalEN. pdf

Zuidema, C., \& de Roo, G. (2015). Making sense of decentralization: Coping with the complexities of the urban environment. In U. Fra.Paleo (Ed.), Risk governance (pp. 59-76). Dordrecht: Springer.

\section{About the Author}

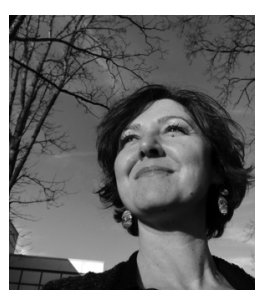

Özge Dolunay is an Environmental Engineer. She received her first MSc degree in Sustainable Resource Management from Munich Technical University and her second MSc degree in Renewable Energy Systems from Vienna University of Technology. She wrote her master's thesis on the permitting and licensing processes of solar and wind energy systems in Turkey. She worked as a Consultant in Solar PV Projects. She is currently doing her PhD at the Social and Population Geography Chair in the University of Bayreuth. 